\title{
Interrogating Citizens' Inequality and Its Impact on Development in Nigeria's Democratic Experience (1999-2019): Imperatives for Leadership Re-Orientation and Resilience
}

\author{
Dr. Ekhosuehi OGHATOR \\ Institute of Public Administration \& Extension Services, University of Benin, Nigeria \\ Dr. Henry Igiebor, OGHOATOR \\ Department of Political Science \& Public Administration, \\ Western Delta University, Oghara, Delta State, Nigeria
}

\begin{abstract}
Nigeria's democratic experience since 1999 has witnessed poor dividends in terms of developmental strides owing essentially to lack-lustre leadership which has resulted in cries of inequality and marginalization. Thus, ethnic militias, tribal conflicts, threats to nationhood, secessionist agitations, etc pervades the Nigerian landscape. In this paper, secondary source of data and content analysis were relied on. The paper opines that the cumulative negative effects of these tendencies on national cohesion and development leave much to be desired. Using Conflict theories of Social Inequality, the paper further opines that one major development challenge confronting Nigeria is the glaring absence of national cohesion and integration which has earned her the appellation of being a mere geographical expression and not a nation. This has been attributed to leadership incompetence that has failed to address emergent leadership cum developmental issues and peculiarities of the federating nationalities. Thus, the ethnic nationalities clamour to hold on to power at the central and be at the commanding heights of political control, resource allocation and disposition, while the minority ethnic nationalities suffer inequality and development is undermined. Hence the calls for self-determination and re-structuring of the country. Interestingly, leadership response overtime is one characterized by absence of theoretical rigour and direction. This paper sought to interrogate the challenges of widening citizens' inequality, marginalization and rights violation, and its nexus with human development on the one hand, while advocating leadership re-orientation and indeed resilience as adequate mechanism for engendering a crop of citizenry who can participate equitably in nation-building and development. Keywords: Democratic, Leadership, Development, Inequality, Resilience.
\end{abstract}

DOI: $10.7176 / \mathrm{DCS} / 10-10-04$

Publication date:October $31^{\text {st }} 2020$

\section{Introduction}

Nigeria which prides itself as the most populous country in Africa sees itself as the most stable and viable country in Africa South of the Sahara judging by its uninterrupted democratic experience since 1999. Nonetheless, the journey so far cannot be said to be rosy given that envisaged democratic dividends i.e. governance and developmental achievements that impacts positively on the citizenry remains unrealized. Indeed the primordial issues of tribalism, nepotism, religious bigotry, corruption, marginalization, rights violation, lopsided appointments to public offices have continued to be the realities of the country's existence.

These have further stretched political and social inequalities that today threatens national cohesion and the call for secession by ethnic nationalities. Indeed formal demands for restructuring of the Nigerian state have continued to resonate in recent times. It needs to be recalled that inequality in the Nigerian space is indeed complex in that it finds expression in several areas viz: gender, religious, geographical and ethno-cultural. An interesting phenomenon that is emerging overtime in the present presidential system of government which is highly distorted in the Nigerian situation, is the over concentration of power in the central government which is under the absolute control of the president. In this regard, the leadership style and behavior adopted by the President goes a long way in determining the direction the country goes vis-à-vis national cohesion, stability and development.

In the recent past and indeed in the period under review, the country's leadership has not lived up to expectations in engendering the required leadership to propel national cohesion, stability and socio-economic development and welfare of the citizenry. Hence, the resounding crises of marginalization and inequality in terms of access to the national purse inspite of immense national wealth and potentials. This has resulted in the rise in conflicts - communal, religious, militancy, etc. which have continued to threaten national unity and development. Examples abound even though the Nigerian state is pretentious about the devastating impact of the activities of these secessionist groups to national development and cohesion. The Boko Haram insurgency in the North-Eastern Nigeria, Armed banditry in all regions of the country, Fulani-herdsmen and farmers' clashes and Niger - Delta militancy etc. are glaring cases. The remote factor that have perpetuated these incidences are not unconnected with perceived inequality and marginalization which the leadership has ignored overtime, hence, these forms of 
resistance which circumulative effect has undermined national development efforts, having regard to unprecedented enormous human, material and financial resources that are brought to bear in containing these insurgencies.

Given this situation therefore, the present writers sought to characterize the leadership style adopted by the Nigerian state, and the extent to which it has propelled inequality amongst the citizenry and the attendant negative impact on National cohesion and development. Furthermore, the way forward by way of leadership approach was also examined in order to mitigate the impending decline of the country to the status of a failed state.

\section{Review of Literature}

The concept of leadership has received the attention of scholars and practitioners in the literature and its attendant issues. It is generally conceptualized "as the process of influencing and supporting others to work enthusiastically toward achieving objectives". On effective leadership, early research according to Newstrom and Davis (2007) suggest that traits - physical, intellectual or personality characteristics are the determinants - such key traits include a high level of personal drive, the desire to lead, personal integrity, cognitive ability, business knowledge, charisma, creativity, flexibility and personal worth etc.

The point is further made by the writers that leadership traits do not necessarily guarantee successful leadership rather they should be seen as competencies or resources which may or may not be developed and used. To them,

Many people have the capabilities to be effective leaders, but some choose not to demonstrate the traits they have. Others may have the necessary traits and the desire to use them, but the opportunity to do so never arises. (Newstrom \& Davis, 2007, p. 201)

Pertinent to this discourse is the issue of leadership style i.e the way in which a leader uses power. Three leadership styles have been delineated as - Autocratic, participative and Free-rein. The Autocratic leadership style is one in which the leaders centralize power and decision making in themselves while at the other extreme is Freerein leadership style in which the leader avoids power and responsibility, leaving the followers to establish goals and work out their problems and issues. Here, the leaders play a minor role. Indeed, "free-rein leadership ignores the leader's contribution in approximately the same way that autocratic leadership ignores the followers. It has the potentiality to degenerate into chaos. In between these extremes, is participative leadership in which authority is decentralized in that decisions are not unilateral as it is the case with the autocrat, i.e leadership style having emerged from consultation with followers and participation by them.

Further elaborating on the concept and dimensions of leadership, Fottler, Malvey \& Slovensky (2017) assert that a single and universally accepted definition of leadership is elusive whilst multiple definitions exist. Citing Northhouse (2009), leadership is conceived as a process whereby an individual influences a group of individuals to achieve a common goal. Perhaps more instructive is the definition by Ciulla (1998) that "leadership is not a person or position but rather a complex moral relationship between people based on trust, obligation, commitment, emotion, and a shared vision of the common good. For Collins (2009) leadership connotes "the leader's ability to motivate or influence others to the point of being a facilitator". It is further held that a leader should be able to adapt quickly in the course of sheparding their charges in turbulent economic and competitive environments by 'altering their leadership approach, the leader can provide the best direction based on the problems encountered'. In a related work, the concept of self- leadership is addressed by Neck and Manz (2007) as 'the process of influencing oneself which implies the behavioral and cognitive tactics used by people for self-direction and selfmotivation to achieve greater personal effectiveness in job or social performance'. Furthermore, these writers present self-leadership in three strategies, viz: self-imposed strategies, self- reward strategies, and self-punishment strategies.

Equally worthy of note, is the assertion by Novelli and Taylor (1993) that :

these diverse concepts of leadership form a spectrum of opinion that, while illustrating some unique traits, also contains common elements: specifically, the need of the leader to possess critical thinking skills. Regardless of which theory of leadership one embraces, critical thinking abilities are a key mechanism to an effective leadership process.

Finally, for Bennis (1994)

Leadership revolves around vision, ideas, direction and has more to do with inspiring people as to direction and goals than with day -to-day implementation. A leader must be able to leverage more than his own capabilities. He must be capable of inspiring other people to do things without actually sitting on top of them with a check list (Bennis, 1994, p.139).

Worthy of mention, in this discourse are the relatively new concepts of servant- leadership and transformation 
leadership. The latter emphasizes commonality of purpose among group members in which the self is put aside while members work for the good of all involved, engendering mutual motivation of one another in order to maximize individual and group potential. The transformational leadership model was introduced by James Macgregor Burns in 1978.

Burns describes transformational leadership as:

a process in which leaders and followers raise one another to higher levels of motivation. Transformational leadership also incorporates principles of social exchange theory, which states that individuals engage in social interactions with the expectation that they will give and receive a benefit or reward. Burns (1978) cited by Harrison (2010, p. 57)

Further expanding the concept of transformational leadership, Northhouse (2001) notes that the model uses transactional and interpersonal relationships to bring about change in a political, social or economic environment experiencing a crisis requiring radical reform. It needs to be further remarked that transformational leaders are essentially concerned with a linkage of their goals and values with that of their followers by developing a common cause. When this is successfully integrated, the leaders become motivators, facilitators, educators and visionaries, while on the other hand, the followers develop a high level of confidence in their direction and engender a sense of loyalty towards them. Hence, transformational leaders "tend to focus on values and internal rewards which may involve such internal motivation techniques as: the use of personal charisma, individual attention to the follower, intellectual stimulation through assignment of tasks, and emotional appeal. Giving credence to the effectiveness of the transformational leadership approach in varying contexts, Howell and Costley (2000) note that: the transformational leadership approach is considered highly effective in situations -whether they be organizational, political, economic or socialin which followers are frustrated, stressed, or unhappy with the current state of affairs. It is also effective in crisis situations. If an individual is able to emerge from the group to represent its desires and needs in such situations, that individuals is likely to become a leader.

Regarding the theory of servant-leadership developed by Greenleaf (1977), the point is succinctly made that: the concept of servant leaders suggests that, endowed with aptitude, certain individuals will assume a mantle of responsibility to provide their followers with an enhanced sense of meaning and value. The leader will, in effect, serve the needs of their followers.

Further, delineating the responsibilities inherent in natural leaders, Greenleaf (1977) identifies two streams, viz: strong leaders and strong servant. Hence the writer asserts that:

Leaders establish the direction and give orders to enforce their decisions. Servants view leadership as an opportunity to enrich their followers. While natural leaders express assertive and domineering qualities to attain a personal goal, natural servants are free of that drive, often instead seeking an altruistic aim and engendering an enhanced level of trust from others.

Exploring the concept of leadership resilience, Luc (2009, p.82) characterizes the concept as "a condition and a consequence of the actualization and exercising of leadership in difficult and demanding situations". Resilience in leaders, it is asserted, is not an end itself; rather it is conceived more of being a path to developing the capacity for accomplishment in the event of adverse conditions. For Coutu (2003) the concept of resilience is viewed more as "a reflex, a way of facing and understanding the world that is deeply etched into a person's mind and soul". A noteworthy attribute is that leaders who survive repeatedly and even thrive in difficult times are often described as resilient and three areas in which leaders should gear up to boost their individual capacity for resilience with respect to their leadership roles are: Proactive self-leadership, intrapersonal intelligence, and good personal health and wellbeing.

Furthermore, resilience conceived as the ability to persevere in the presence of adversity can be learned and developed. The point is made that individuals need to identify their existing capacity, and work towards developing higher levels of leadership resilience by reinforcing those areas in which they are weak, and ultimately their capabilities to contribute to the successful outcome of the team or organization's strength. Hence, it is averred that resilience is all about "continuously anticipating and adjusting to the challenges faced as leaders and using the skills that are developed during those situations to increase and maintain resilience levels". On the whole, a number of personal attributes of resilient leaders made apparent in the literature include: internal locus of control, professionalism, empathy, a positive self-image, optimism and the ability to organize and lead complex operational responsibilities during unexpected adversity of rapid change. (Fottler, Malvey \& Slovensky, 2017).

In a related assessment of the performance of the Buhari-led administration since being on the saddle five years ago which bothers on leadership, the Vanguard Newspaper (Friday, May 27, 2020) comments that whereas 
the administration has done well in the sphere of infrastructural development and maintenance of a stable foreign exchange regime, the editorial remarks that with respect to social investment programme, especially the component of conditional Cash Transfer, (for the poorest and most vulnerable) and the school feeding programme, "the implementation has been shrouded in controversy due to lack of transparency". The paper further poses pertinent questions thus:

In what ways has Buhari's coming made Nigeria worse than he met it? Buhari and his All Progressive Congress (APC) had campaigned on the change mantra, How much has changed for the better? (Vanguard Newspaper, May 29, 2020, p. 18)

Editorial and Commentaries of this nature abound suggesting non-serious consideration for closing the inequality gaps in the country.

Furthermore reviewing President Buhari's Fifth year in office, the Guardian editorial (Friday May 29, 2020) wondered whether Nigeria is better off than it was five years ago. The paper notes that for the Buhari administration,

The state of the economy is very bad. Inflation, high interest rates, debt burden, huge wage bill, unemployment have been on the rise till the present. A critical economic infrastructure like power supply has also been deplorable against all promises and expectations. Cost of living has risen in the face of increased electricity and fuel prices and living standard for the majority of the people are at the lowest.

The point is made that the government is run on promises for which no serious effort is put to achieving same. On security, the paper avers that

While there has been marked improvement in the war against Boko Haram, the score card of this administration in terms of comprehensive national security and national integration is below par. In fact the administration's handling of widespread insecurity as swinging between incompetent, insensitive and seeming complicity.

In concluding, the newspaper admonishes the President to pay attention to restructuring of the federation as the present unitary structure that encourages indolence and lack of creativity cannot lead to progress".

In yet another letter to the President in the Punch Newspaper (June 1, 2020) titled "Your loop-sided appointments will ruin Nigeria" Abubakar Umar noted that Nigeria had become dangerously polarized and risk sliding into crisis on account of Buhari's loop-sided appointments. In his words, the retired army warned that:

Skewed appointments into the offices of the federal government, favouring

some and frustrating others, shall bring ruin and destruction to this nation.

From the foregoing exploration of the extant literature, it is to be noted that scholars have indeed examined the rudiments of leadership as the pivot upon which societal or organizational success revolves and that no one approach suffices in all situations. It therefore behoves leadership in whatever contexts to be resilient and responsive to changes. Equally, authors have acknowledged the widening inequality be it political, economic or gender based that appears to be on the increase. However, the issue of how inequality has negatively impacted development especially in developing countries has not attracted much attention. Not much work is directly available as to establishing a nexus between the slow pace of development and the widening inequality amongst the citizenry of developing countries, and in this case, Nigeria owing to poor leadership approach to redressing the issues through reorientation and resilience. It is to the extent of filling the gap in literature that the present study is undertaken.

\section{Theoretical Framework}

The present study hinges on the conflict theories of social inequality theory propounded by Karl Marx and his followers. Social conflict theory views society as an arena where conflict takes places as a result of inequality which is a function of race, class, sex etc which are built into any society resulting in conflict and dominance of one group over other ethnic group(s) in the same society or political system. Social conflict is a struggle waged by a group for a common cause. It involves coercive power and domination. Conflict occurs when individuals or people interrelate.

The Marxian view point of social conflict states that social class and inequality emerged because the social structure is based on conflict and contradictions over scarce resources rather than on consensus. The conflicting groups tend to attain more of the available resources resulting in the exploitation of the less powerful group and this deepens inequality in the political system.

Jim Chappelow (2020) alluded to the statement above when he asserted that society is in a state of perpetual conflict because of competition for limited resources. He asserts that conflict theory holds that social order is maintained by domination and power and that those with wealth and power try to hold on to it by suppressing the less powerless.

Social conflict theory is an integral factor in shaping social life which is characterized by conflicts among individuals, social groups, political parties etc. This paper is drawing inference from the work of Ewa Szczecinska - Musielak titled Social Conflict theory in studying the conflict in Northern Ireland. In the same vein this paper is 
interrogating using social conflicts theory as analytical tool in explaining ethnic capabilities affecting inequality and development in Nigeria.

\section{Inequality and Development}

Dudley Seer stated that one parameter for assessing development is inequality He asserts that as inequality is on the increase, development is hampered.

This paper intends to provide answer to the question. Does inequality affect the development of nations albeit Nigeria and to what extent?

Broadly defined, inequality is the difference in wealth between individuals and groups in a given society or societies. In the literature, two (2) basic types have been identified namely, economic inequality which consists of income, wealth and consumption on the one hand, and inequality of opportunities on the other hand. This second variant can be explained using gender, ethnicity, geographical area. In Nigeria, the inequality of opportunities dictates the economic inequality.

Gajardo's studies reveal that inequity aversion leads to socio-political unrest

Inequality motivates the oppressed to engage in crime, riot and disruptive activities. Thus, time that would have been devoted for developmental efforts are wasted. Nigeria is replete with

Social Unrest as a result of conflicts, underdevelopment as a consequence of inequality and inequality exacerbating and affecting the level and rate of development

\section{Research Methodology}

The study utilized the qualitative research design at which two focused group discussions were held under the guidance of the researchers and two assistants. The groups comprised relevant stakeholders i.e. university students, lecturers, politicians and public servants, NGOs and women groups. Each group comprised of eighteen (18) and fourteen (14) participants drawn from Benin City, Edo state, Nigeria. This arrangement ensured broad based participation with a view to garnering information from knowledgeable stakeholders who were willing to participate voluntarily in the discussions sessions. Other secondary sources of data included newspaper commentaries, documentary evidence and published works on the issues of concern. The focus group discussions were recorded, transcribed and subjected to thematic content analysis manually by coding and delineating the emerging themes.

\section{MAJOR FINDINGS AND DISCUSSION OF FINDINGS:}

The study revealed majorly that inequality and poverty in Nigeria was on the increase and assuming unimaginable proportions. About $90 \%$ of the participants highlighted the features of inequality to be gender-based and regional in nature. Women were considered to be mostly affected as they have no access to empowerment provisions, little or no income when compared with their male counterparts. Hence, their participation in community development efforts was greatly hampered. They are forced to resort to petty trading and farm work at the subsistence level. Noteworthy, is the assertion that governments efforts at reducing the inequality gap leaves much to be desired. Regarding the trader moni initiative by the Federal Government of Nigeria, Lucy - a participant remarked thus:

That was a political gimmick by the government to buy votes as it was done during the electioneering period for only identified card-carrying members of the party.

This statement was essentially corroborated by others who claimed that the real traders did not benefit from the empowerment programmes. It was reasoned that organized women groups, and registered NGOs and community-based organizations ought to be used for implementing women empowerment programmes if the government was serious in addressing gender inequality with a view to boosting development initiatives.

Yet another dimension to inequality revealed in the study has to do with inequality characterized as ethnic/ regional, and religious. This obtains more in appointment to government positions. It was the general opinion of the discussants that more than ever before, appointments to key ministries, departments and Agencies in Nigeria today, does not reflect competencies in skills as orchestrated adherence to Federal character principles. Rather considerations are not based on relevant academic and professional qualifications, but adherence to religious affiliations, and geographical cum ethnicity. It is no wonder therefore, according to one- participant (John) that:

How can Nigeria develop, when key appointments are lop-sided in

favour of Northern Fulani Muslims who have dominated all aspects of National life?

Attention is drawn to the fact that inspite of the outcry of citizens on the inherent dangers and negative impact of mediocre appointments on development, the central government is unperturbed. Little wonder the call for restructuring and constitutional amendment to entrench true federalism or co-federalism while others preach secessions and breakup of the country. It is to be noted further that there exist lop-sided allocation of resources to areas where they cannot be brought to good use to the detriment of other parts of the country where its utilization 
would have impacted positively on the citizenry and development of the nation. A case in point according to Elsie another discussant is the location of a Maritime University and five-star hotel in Daura -Katsina State which is desert and of zero tourist potentials. The choice of location for these projects was simply borne out of the fact that the Nigerian President hails from that part. She goes further to cite the multi-billion dollars railway project linking Daura to Niger republic which is of no economic or development value whereas what is needed most is railway to connect the oil-rich South to the North with substantial agricultural produce. A sad situation, she laments.

It is therefore not surprising that Nigeria given the enormous resources available to it, remains a poor country and clueless leadership has no doubt further worsened the case leaving the citizenry with widening inequality and access to good living. Hence, the country has been rechristened the poverty capital of the world. The leadership predicament of the Nigerian state is aptly captured by Awosiyan Segun (Vanguard May, 6, 2020) which depicts religion and leadership as the top-most hindrance to development in Africa, to which many writers have alluded to in the literature.

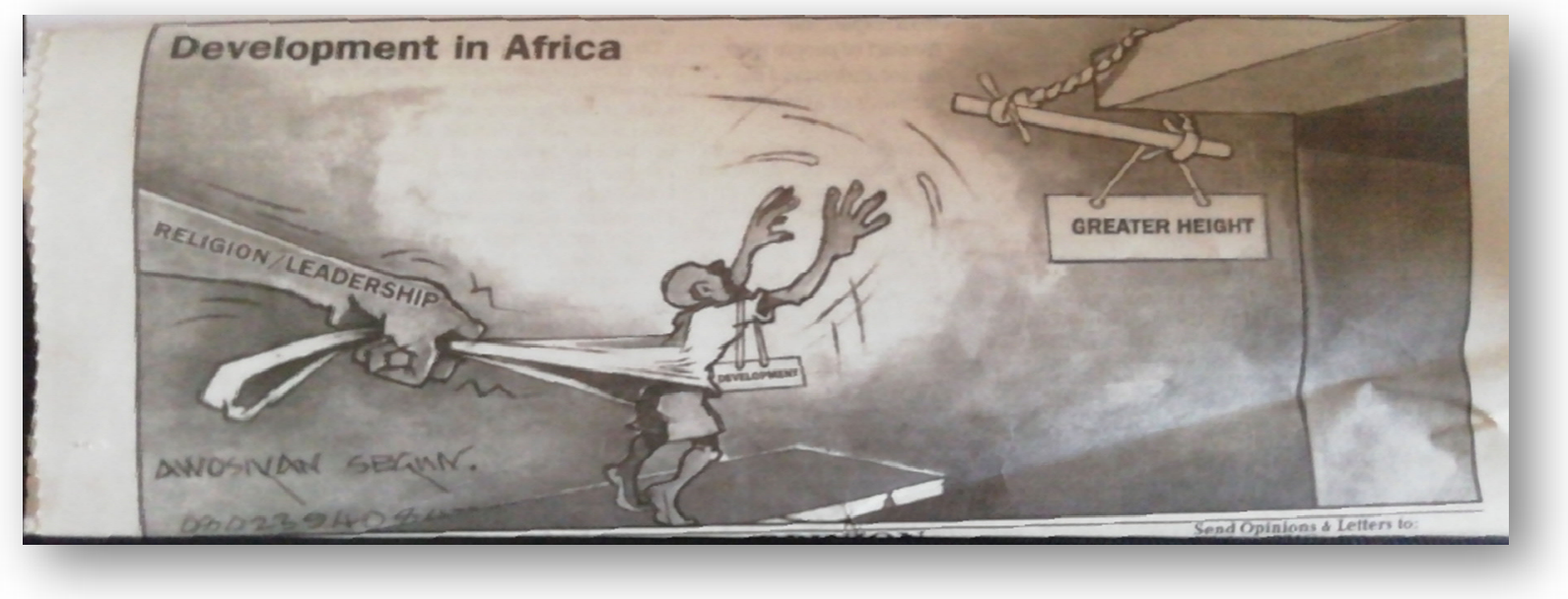

Fig 1

On the whole, the point is made by the participants that Nigeria's democratic experience (1999- till date) has witnessed abysmally poor democratic dividends owing to the dominance of the political and bureaucratic space by the Northern Fulani Muslims who have held on to power and governance without regard to the Federal structure. The current travails of the nation i.e. armed banditry, the Boko-Haram Insurgency, Niger-Delta militancy etc were considered to be the offshoots of widening inequality fuelled by inept leadership that has failed to respond effectively to the yearnings of the citizenry. In this regard, Ernest opined that Nigeria's leadership overtime, rather than being resilient by way of taking the followers concerns and well-being into consideration in the pursuit of goals and policies, are more or less aloof and nonchalant pursuing policies that favour their cliques, hence the glorification of corruption amongst politicians and bureaucrats. Monies that would have been used for developmental purposes have been carted away by individuals and public officials, and regrettably, there has been no high-profile prosecutions and repatriation and proper use of such stolen funds till date. The laissez-faire leadership behavior of government functionaries has according to the research participants energized the disdain with which public funds are looted by party loyalists with no serious attempts at prosecutions. To this end, the majority opinion is that for the Nigerian nation to come out of the woods, there is the urgent need for leadership re-orientation and resilience. It is canvassed that anyone aspiring to political leadership and indeed at any level, must fully understand the intricacies of participative leadership, possess leadership qualities and competencies to respond to the vagaries of leadership as they occur, and do the needful and not wait till crisis occurs as it is in Nigeria today.

Yet another issue that emerged from the focus group discussion, is the prevalence of crisis in Nigeria spanning political, religious and economic terrains. Indeed, while some crises are full-blown, like the Boko-Haram insurgency that have defiled solution since 2009, armed banditry and kidnapping and others are brewing. The situation has necessitated setting up of regional security outfits given the failure of the nation's security architecture to stem the tide by concerned states. What this suggest is that in the absence of peace, more funds that would have been reasonably applied to developmental programmes and projects would be used to address conflicts and insurgencies.

On the way forward, the participants aver that in order to stem the incidence of inequality and marginalization which are detrimental to national integration and development, restructuring of the Nigerian state is not only necessary to cater for sectional interests and well-being. This is against the backdrop that the Federal character principle and the leadership have not been brought to bear in ensuring an integrated society where all citizens have 
fulfilled dreams that can contribute to national development.

Further canvassed is the need for leadership re-orientation with a view to imbibing resilience and participation of all and to reduce to its barest minimum support for primordial divisive factors like ethnicity, religious bigotry and enthronement of incompetence in key developmental areas. For it is in this wise that national development can take place.

On what seems a note of despair, Col. Abubakar Umar (rtd) is quoted to have remarked that:

All those who wish you and the country well must mince no words in warning you that Nigeria has become dangerously polarized and risks sliding into a crisis on account of your administration's lopsided appointments which continue to give undue preference to some sections of the country over others.

Further corroborating the foregoing views, the Guardian Newspaper Editorial (June 2, 2020) titled: Buhari and his Federal Character Virus". Notes that "the biggest trouble with the Buhari Administration is the elephant in the room variously tagged as "lopsided appointments, nepotism, sectionalism, parochialism, etc".

Numerous instances were reported at which President Buhari has consistently failed to respect the federal character provision in the country's constitution which was designed to address "lopsided appointments and build peace that has eluded Nigeria since independence in 1960. While noting the complex diverse nature of the country which spans across culture, ethnicity, language, religion and natural resources amongst others which makes the country heterogeneous, the editor's reminds every one that

Our founding fathers and minds behinds our constitution recognized the primacy of heterogeneity and inclusiveness in the making of peace and progress of the country. Specifically, the 1979 constitution adopted the federal character principle to orchestrate elusive peace, equity and stability. It was to make amends for inter-ethnic distrust, dominance, rivalry, conflicts and wars. Section 14(3) (4) and the third schedule, Part 1 (c) of the constitution spell out the principle in clear terms. And to ensure implementation, the Federal Character Commission was in 1996 established.

The point made by the writers is that the "subsisting constitutional provision has been honored in the breach than in its observance by the Buhari-led administration". The conclusion is reached:

His (Buhari's is a presidency that has for five years belonged more to Northerners than to all Nigerians - the electorate. If not, let Nigerians see fairness, equitable distribution of appointment to our best hands across the country, and give every member of this entity a sense of belonging. It is a step in the right direction to secure the future of one Nigeria by respecting the letter and the spirit of the constitution, which Buhari has on two occasions sworn to depend. It is hoped that our leader realizes the consequences of a breach of the organic law of the land- the constitution. (the Guardian, June 2, 2020)

The foregoing are the instances of citizens' dissatisfaction with the rising state of inequality and the fear of emerging crisis and destructions of national psyche

\section{Conclusion}

This paper sought to draw a nexus between inequality as a developmental concern and how leadership behavior could impact on the realization of developmental strides in Nigeria's fledgling democratic experience (1999-date). The research sought to characterize inequality and leadership styles, employed in the Nigerian state and how it has impacted on the desire for development. Focused group discussions data revealed amongst other issues the features of inequality which is obviously on the increase, to include ethnic, gender and religious inequalities which has impacted negatively on all forms of development in Nigeria. Also noted is the rising lop-sided appointments and access to national resources as a complete departure from the federal character principle. The situation which is providing basis for agitation for restructuring of the country and or outright secession by groups of ethnic nationalities, has been wittingly encouraged by lack-lustre leadership that tends to be inept and divisive given its non-proactive posture and poor resilience attitude to leadership and governance. The pre-ponderance of crisis religious and political, armed banditry, insurgency, kidnapping, piracy, etc in Nigeria are manifestations of this leadership unresponsiveness. Hence the recommendation that for development to obtain, peace is essential which only a resilient leadership can bring about and sustain for national stability.

\section{REFERENCES}

Bennis, W. (1994) On Becoming a Leader: Reading, MA : Addison- Wesley Publishing.

Burns, J. M. (1978) Leadership. New York : Harper \& Row.

Chariantein Ivan Partal Gajardo (2016) "Inequality and Its impact on Development" Available at dugidoc.udg.edu/bitstream/handle/10256/13887/partal_Gajardo.pdf.pdf?sequence=1

Ciulla, J.B (1998) Ethics: The Heart of Leadership. Westport, CT: Praeger Publishers. 
Collins, J. (2009) How the Mighty Fall: And why some companies never give in. London: Random House Business.

Ewa Szczecinska - Musielak. "Social Conflict Theory is Studying the Conflict in Northern Ireland in Polish. Sociolgical review .eu/wp-content/upload/2016/4/psr193-08.pdf..Cited 3-2-2020.

Fotler, M.D, Malvey, D. \& Slovensky, D.J (2017) Cheltenham, Handbook of Healthcare Management. UK: Edwards Elgar Publishing

Greenleaf, R. K. (1997) Servant Leadership. New York: Paulist Press.

Harrison, J. P (2010) Essentials of Strategic Planning in Healthcare. Chicago, Illinois: Health Administration Press.

Howell J.P \& Costley, D.L (2000) Understanding Behaviours for Effective Leadership. Upper Saddle River, N.J: Prentice Hall.

Isenyo, G (2020) "Your lopsided appointments will ruin Nigeria, Umar tells Buhari”. In Punch Newspaper, June $1,2020$.

Jim Chappelow (2020) “Conflict theory” in investopedia.com/terms/c/conflict-theory.asp cited 1-5-2020

Luc, E. (2009) Unleashing Your Leadership Potentials: Seven Strategies for Success. Lanham, M.D : Rowman \& Little field Education.

Mehrdad Vahabi (2009) "A Critical Review of Strategic Conflict Theory and Socio-Political Instability Models" in: Dans Revve D'Economic Politique. PP. 817-858. Available at www.cairn.info/revve-d-economicpolitque-2009-6-page817. Cited 15-2-2020

Neck C.P \& Manz (2007) Mastering Self-leadership: Empowering Yourselffor Personal Excellence. Upper Saddle River, N J: Pearson Prentice Hall.

Newstrom, J.W \& Davis, K. (2007) Organisational Behaviour: Human Behaviour at Work. Boston, Massachusetts: McGraw Hill Companies Inc.

Northhouse, P.G. (2009) Leadership: Theory and Practice. London: Sage Publications, Inc.

Novelli, L \& Taylor, S. (1993). The Context for Leadership in 21 st century Organisations: A role for Critical Thinking. American Behavioural Scientist, 37, 139-147

Social conflict theory cited 12-2-2020 available at en.wikipedia.org/wiki/social_conflict_theory.

The Guardian Newspaper. "Buhari’s Fifth Year: Lingering Hopes and Barriers”. Friday, May 29, $2020: 12$.

The Guardian "Buhari and His Federal Character Virus ". June 2, 2020.

Vangard Newspaper: "Buhari's Five Years in the Saddle”. Vanguard Comment, Friday, May 29, 2020 Page 18

\section{AUTHORS:}

M.E Oghator, Ph.D is a lecturer and the Director of the Institute of Public Administration and Extension Services ( IPAES) University of Benin.

H.I Oghoator, Ph.D is a lecturer in the Department of Political Science and public Administration and he is the Dean of College of Social and Management Sciences, Western Delta University .Oghara. Nigeria 